\title{
PENGARUH PERBEDAAN PROPORSI TEPUNG DAUN SIRSAK (Annona muricata L.) DAN TEH HITAM TERHADAP AKTIVITAS ANTIOKSIDAN DALAM MINUMAN
}

\author{
(The effect of different proportions of Soursop leaf (Annona Muricata L.) \\ and Black Tea on the antioxidant activity in beverage)
}

\author{
Tarsisius Dwi Wibawa Budianta ${ }^{a_{*}}$, Paini Sri Widyawati ${ }^{a}$, Venny Haditanojo ${ }^{a}$ \\ ${ }^{a}$ FakultasTeknologi Pertanian, Universitas Katolik Widya Mandala Surabaya, Indonesia \\ ${ }^{*}$ Penuliskorespondensi \\ Email: tdwiwibawabudianta@ukwms.ac.id
}

\begin{abstract}
Black tea is a product that is rich in antioxidant content. Soursop (Annona muricata L.) is initially planted for its fruit, but nowadays the soursop leaves are also taken because it has been discovered the good effect of soursop leaves for human health. The soursop leaves and black tea both contain phytochemical compounds which act as antioxidant that have the potential to fight free radicals and reducing the risk of degenerative diseases. The high amount of phytochemical compounds in both soursop leaves and black tea are predicted to be mutually stimulate antioxidant activity in beverage. The research is done to determine the effect of different proportions of soursop leaf and black tea on antioxidant activity in beverage. The experiment is using randomized block design (RBD) with one factor which is difference in proportions of soursop leaves and black tea with six levels i.e. 0:100, 10:90, 20:80, 30:70, 40:60, 50:50 and $100: 0 \%(\mathrm{~W} / \mathrm{W})$ as control. The parameters observed are total phenol, total flavonoids, antioxidant activity with DPPH (2,2-diphenyl-1-picrylhydrazyl), iron ion reducing power, and supported by identification of phytochemical compounds. The results showed that the different proportions of soursop leaf and black tea significantly affected on physicochemical compounds, total phenol, total flavonoid, antioxidant activity with DPPH, and iron ion reducing power of beverage. Total phenol ranged from 0.83$4.48 \mathrm{mg}$ CE/L sample, DPPH scavenging activity ranged from $0.63-2.47 \mathrm{mg}$ GAE/Lsample, and iron ion reducing power ranged from 19.47-54.25 $\mathrm{mg}$ GAE/L sample.
\end{abstract}

Keywords: soursop leaf, black tea, antioxidant, phenol, flavonoid

\section{ABSTRAK}

Teh hitam merupakan salah satu produk yang kaya akan kandungan antioksidan. Tanaman sirsak (Annona muricata L.) yang awalnya ditanam secara komersial untuk diambil daging buahnya, sekarang juga diambil daunnya kerena telah ditemukan khasiat daun sirsak untuk kesehatan. Daun sirsak dan teh hitam keduanya mengandung senyawa fitokimia yang berperan sebagai antioksidan yang berpotensi untuk melawan radikal bebas dalam tubuh sehingga dapat menurunkan resiko penyakit degeneratif. Tingginya kandungan senyawa fitokimia dalam teh hitam dan daun sirsak diduga dapat saling menstimulasi aktivitas antioksidan dalam minuman. Rancangan penelitian yang digunakan adalah Rancangan Acak Kelompok dengan satu faktor yaitu perbedaan proporsi tepung daun sirsak dan daun teh hitam dengan enam taraf perlakuan yaitu 0:100, 10:90, 20:80, 30:70, 40:60, 50:50, dan 100: 0\% (b/b) (sebagai kontrol), dengan 4 replikasi tiap perlakuan dan pengujian analisis varian dengan taraf signifikansi $5 \%$. Parameter yang diuji adalah kadar fenol, kadar flavonoid, analisa aktivitas antioksidan dengan metode DPPH (2,2-diphenyl-1-picrylhydrazyl), kemampuan mereduksi ion besi, dan pengujian identifikasi senyawa fitokimia sebagai pendukung. Hasil penelitian menunjukkan terdapat pengaruh proporsi tepung daun sirsak dan teh hitam terhadap sifat fisikokimia, kadar total fenol, total flavonoid, 
kemampuan menangkal radikal DPPH dan kemampuan mereduksi ion besi pada produk minuman teh daun sirsak. Kadar total fenol berkisar antara 5,61-25,17 mg GAE/L sampel, kadar total flavonoid berkisar antara 0.83-4,48 mg CE/L sampel, kemampuan menangkal radikal DPPH berkisar antara 0,63-2,47 mg GAE/L sampel, dan kemampuan mereduksi ion besi berkisar antara 19,47-54,25 mg GAE/L sampel.

Kata kunci: daun sirsak, teh hitam, fitokimia, fenol, flavonoid, aktivitas antioksidan

\section{PENDAHULUAN}

Kebutuhan terhadap bahan pangan yang sehat semakin meningkat dikaitkan dengan semakin banyaknya penemuan penyakit degeneratif yang diderita umat manusia seperti kanker, liver, jantung koroner, stroke dan diabetes. Penyakit degeneratif tersebut dapat ditanggulangi dengan konsumsi bahan pangan yang mengandung senyawa antioksidan, yang banyak terdapat pada tanaman di sekitar kita, yang kemudian dikatakan sebagai tanaman yang berkasiat. Kebutuhan terhadap bahan pangan yang sehat semakin meningkat dikaitkan dengan semakin banyaknya penemuan penyakit degeneratif yang diderita umat manusia seperti kanker, liver, jantung koroner, stroke dan diabetes. Penyakit degeneratif tersebut dapat ditanggulangi dengan konsumsi bahan pangan yang mengandung senyawa antioksidan, yang banyak terdapat pada tanaman di sekitar kita, yang kemudian dikatakan sebagai tanaman yang berkasiat.

Pemanfaatan tanaman berkasiat mempunyai peranan penting dalam menjaga kesehatan manusia sejak beribu tahun lalu hingga saat ini. Tanaman berkasiat merupakan dasar dalam pengobatan tradisional dan sebagai sumber nutrisi bagi umat manusia. Tanaman dengan kasiat obat telah digunakan sebagai pengobatan alternatif untuk penanganan berbagai penyakit baik di negara maju maupun negara berkembang. Sehingga kajian farmakologis herbal tradisional menjadi bagian yang sangat kritis dalam kesehatan global (Osathanunkul, 2018). Tanaman yang berkasiat ini karena dapat dimanfaatkan sebagai makanan yang berkasiat kesehatan dan menjaga fungsi kesehatan, maka kemudian dapat digolongkan menjadi sumber pangan fungsional. Tanaman golongan ini yang sudah sejak lama dikenal dan dimanfaatkan antara lain adalah tanaman teh dan tanaman sirsak.

Tanaman teh dimanfaatkan dengan cara memetik daun teh, kemudian diolah menjadi berbagai jenis teh antara lain teh putih, teh hijau, oolong tea dan teh hitam. Teh hitam merupakan penyebutan untuk teh kering yang dihasilkan dari pucuk daun tanaman teh (Camelia sinensis) yang melewati tahapan fermentasi secara penuh (Graham, 1992). Teh selanjutnya diseduh dan siap dikonsumsi sebagai minuman. Minuman teh hitam ini sangat disukai oleh masyarakat dunia karena memiliki rasa dan aroma yang khas serta memberikan efek yang baik bagi kesehatan tubuh (Ljubuncic, 2005). Beberapa penelitian telah melaporkan bahwa mengkonsumsi teh secara teratur dapat mereduksi dan mencegah penyakit degeneratif seperti penyakit jantung, hipertensi, diabetes, kegemukan, kanker, dan sebagainya (KrisEtherton et al., 2003). Senyawa yang berperan untuk mencegah penyakit degeneratif adalah senyawa antioksidan dengan menangkal radikal bebas dan menghambat proses oksidasi. Penelitian mengenai pengaruh ekstrak teh hijau dan teh hitam pada glukosa kontrol pada orang dewasa dengan diabetes mellitus tipe 2 (Mackenzie et al, 2007) menunjukkan hasil tidak ada beda pengaruh keduanya terhadap kontrol glukosa. Banyak manfaat teh yang sudah diteliti dan dilaporkan antara lain sebagai immunomodulator, antigenotoxic, melawan penyakit jantung (cardiovascular diseases), cancer prevention, chemoprevention of prostate 
cancer, sifat hepatoprotective, melawan obesitas, sifat antibakteri dan antivirus, serta antidiabetes sehingga teh digolongkan produk yang mempunyai protective effects untuk kesehatan manusia (Jain et. al., 2006). Dari penelitian Nishiumi et. al, (2010) ditemukan kemampuan teh hijau dan teh hitam dalam menekan hiperglikemia dan resistensi insulin. Peneliti dari Srilangka pada tahun 2011 menemukan sifat hipoglikemik, antihiperglikemik, dan aktivitas antidiabetik dari teh hitam pada teh hitam grade broken orange pekoe fanning (BOPF) (Abeywickrama et. al., 2011). Semua kemampuan ini disebabkan oleh senyawa polifenol teh yang berperan sebagai antioksidan.

Tanaman sirsak (Annona muricata L.) mengandung senyawa bioaktif fitokimia salah satunya adalah senyawa Annonaceous acetogenins (ACGs), yang terdapat pada batang, daun, buah, biji, dan akarnya. Senyawa ACGs adalah senyawa poliketida dengan struktur C-34 atau C-37 rantai karbon tidak bercabang yang terikat pada gugus C-34 atau C-37 rantai karbon tidak bercabang yang terikat pada gugus 5methyl-2-furanone (Hermawan dan Laksono, 2013). Senyawa ACGs memiliki 350 senyawa turunan yang ditemukan pada famili Annonaceae dan sebanyak 82 diantaranya terkandung dalam tanaman sirsak (Chang et al., 2002). Senyawa tersebut telah menunjukkan efek anti-tumor, anti-mikroba, anti-malaria, dan lainnya. Sifat-sifat ini yang menunjukkan bahwa setiap bagian dari tanaman sirsak berpotensi untuk diaplikasikan dalam upaya meningkatkan kesehatan. Penelitian kemampuan sirsak untuk antikanker telah diteliti oleh Najmudin et al. (2016). Telah diteliti pula minuman teh sirsak yang populer di Thailand sebagi obat anti kanker (Osathanunkul, 2018). Penelitian untuk mendapatkan komponen fenolik dari daging buah dan bahan samping dari sirsak telah dilakukan oleh Aguilar-Hernandez et al. (2019).
Untuk mendapatkan manfaat yang optimal dari bahan alami yang ada, maka diduga dengan mencampur kedua bahan alami yaitu tepung daun sirsak dan teh hitam, mendapatkan aktivitas antioksidan yang lebih optimal. Tujuan dari penelitian ini adalah untuk mengetahui pengaruh penambahan dengan proporsi yang berbeda campuran antara tepung daun sirsak (Annona muricata Linn) dan teh hitam terhadap aktivitas antioksidan dalam minuman.

\section{BAHAN DAN METODE}

\section{Bahan}

Bahan baku yang digunakan adalah teh hitam yang diolah menggunakan metode CTC (Curling Tearing Cutting) dari PTPN XII Lawang dengan premium grade dan daun sirsak dengan ruas daun nomor 4 hingga 6 dari pucuk yang diperoleh dari Jalan $\mathrm{KH}$ Wahid Hasyim, Banyuwangi.

Bahan kimia yang digunakan untuk analisa adalah dengan grade untuk analisis (p.a.) antara lain asam galat (RiedeldeHaen), DPPH (2,2-diphenyl-1picrylhydrazyl)(Sigma), methanol (Fulltime), etanol (JT Baker), etil asetat (JT Baker), heksana (JT Baker), kloroform (Merck), merkuriklorida (PT Brataco), kalium lodida (Merck), lodin (Merck), $\mathrm{NaOH}$ kristal (Merck), ether (PT Brataco), asam asetat glacial (Merck), Fe(III) klorida (Merck), asam klorida(Merck), n-amil alcohol (Merck), Mg serbuk(Merck), tembaga (II) sulfat (Merck), folin-ciocalteu kalium ferrisianida (Merck), natrium nitrit (Merck),kalium Na-tartrat tetrahidrat (Sigma-Aldrich), natrium karbonat (Riedel-de Haen), (+)-katekin (Sigma) aluminium klorida (Schuchardt $\mathrm{OHG}$ ), aquades (PT Surabaya Aqua Industry), asam triklorosetat (RiedeldeHaen).

\section{Preparasi Bahan}

Daun sirsak ruas keempat hingga keenam dipetik, kemudian disortasi untuk memilih daun yang berkondisi baik, 
kemudian dicuci dmenggunakan alir mengalir dengan tujuan untuk mengurangi jumlah kontaminan pada daun sirsak. Daun sirsak dilayukan selama 7 hari pada suhu kamar dengan tujuan untuk mempermudah proses pengeringan selanjutnya. Pengeringan daun sirsak menggunakan cabinet dryer dengan suhu $50^{\circ} \mathrm{C}$ selama 30 menit hingga kadar air mendekati $6 \%(\mathrm{db})$. Untuk teh hitam dipilih yang premium grade dengan kadar air mendekati 6\% (db). Daun sirsak dan teh hitam masing-masing ditepungkan menggunakan blender, kemudian diayak menggunakan ayakan rumah tangga(28 mesh). Masing-masing tepung dikemas menggunakan plastik PE dan aluminium foil, selanjutnya disimpan di refrigerator.

\section{Metode pengolahan}

Untuk proses penyiapan selanjutnya adalah bahan yang disimpan di refrigerator diambil, kemudian ditimbang dengan proporsi tepung daun sirsak dan teh hitam dengan enam taraf perlakuan yaitu 0:100, 10:90, 20:80, 30:70, 40:60, 50:50, dan 100: $0 \%$ (b/b) untuk tiap 2 gram campuran. Dibuat masing-masing campuran untuk tiap perlakuan sebanyak 10 kemasan. Kemasan yang digunakan adalah kantong teh (tea bag) yang menggunakan kertas saring standar ISO, kemudian diberi benang selanjutnya direkatkan menggunakan sealer. Dari 10 kantong camputan teh daun sirsak tersebut dipilih 4 kantong diantaranya untuk diseduh. Penyeduhan satu kantong teh daun sirsak dilakukan dalam $150 \mathrm{ml}$ air bersuhu $85 \pm 2{ }^{\circ} \mathrm{C}$ selama 5,5 menit tanpa penutupan. Selanjutnya dilakukan pengujian sampel dengan memperhatikan jeda waktu pengambilan sampel seduhan hingga analisis adalah antara 10-15 menit.

\section{Metode pengujian/cara analisis}

Dari bahan yang sudah diseduh menjadi minuman teh daun sirsak, selanjutnya diuji identifikasi senyawa fitokimia (Harborne, 1996), analisis kadar total fenol (McDonald et al., 2001), analisis kadar total flavonoid (Al-Temimi dan Choundary, 2013), analisis aktivitas antioksidan metode DPPH (Rekha et al., 2012), analsis kemampuan mereduksi ion besi (Al-Temimi dan Choundary, 2013). Sedangkan kadar air bahan baku teh dan tepung sirsak dianalis kadar airnya menggunakan metode oven vakum (AOAC, 1995).

\section{Analisis Statistik}

Data yang diperoleh pada penelitian ini dilaporkan dalam bentuk rata-rata \pm standar deviasi, dan diuji menggunakan Analisis Variansi (Analyisis of Variance) dengan taraf signifikansi (a) 5\%. Apabila ada perbedaan yang nyata maka dilanjutkan dengan uji perbedaan antar perlakuan menggunakan uji post-hoc Duncan Multiple Range Test (DMRT). Analisis statistik dilakukan menggunakan SPSS versi 2016.

\section{HASIL DAN PEMBAHASAN}

Dari hasil pengujian kadar air tepung sirsak diperoleh kadar air sebesar $5.87 \%$ (db) dan teh hitam $5.21 \%(d b)$. Kadar air tersebut digunakan untuk menentukan kadar air campuran teh daun sirsak secara proporsional sesuai proporsi perlakuan, dan digunakan sebagai informasi tambahan dalam analisis. Adapun hasil analisis terhadap seduhan sesuai dengan metode analisis masing-masing diuraikan sebagai berikut:

\section{Senyawa Fitokimia}

Identifikasi senyawa fitokimia dalam seduhan teh daun sirsak dilakukan secara kualitatif dengan cara pengamatan terhadap intensitas warna larutan. Analisis yang dilakukan meliputi alkaloid, fenolik, flavonoid, triterpenoid, sterol, saponin, tanin, kardiak glikosida. Analisis ini mendahului dan mendukung pengujian aktivitas antioksidan secara kuantitatif. Hasil identifikasi senyawa fitokimia (Tabel 1.) menunjukkan hasil positif secara kualitatif, sehingga dapat dilanjutkan dengan analisis kuantitatif. Hasil analisis menunjukkan pada P1 mengandung senyawa fitokimia dengan kadar yang paling tinggi dilihat dari intensitas warna larutan yang terbentuk. Kadar fitokimia terlihat menurun secara 
Tabel 1. Senyawa Fitokimia dalam Minuman Teh Hitam Daun Sirsak

\begin{tabular}{lccccccc}
\hline \multirow{2}{*}{$\begin{array}{l}\text { Senyawa } \\
\text { Fitokimia }\end{array}$} & \multicolumn{7}{c}{ Perlakuan } \\
\cline { 2 - 8 } \multicolumn{1}{c}{} & $\mathrm{P} 1$ & $\mathrm{P} 2$ & $\mathrm{P} 3$ & $\mathrm{P} 4$ & $\mathrm{P} 5$ & $\mathrm{P} 6$ & Kontrol \\
\cline { 2 - 8 } & $0: 100$ & $10: 90$ & $20: 80$ & $30: 70$ & $40: 60$ & $50: 50$ & $100: 0$ \\
\hline Alkaloid & +5 & +4 & +3 & +3 & +3 & +2 & +2 \\
Fenolik & +5 & +3 & +5 & +4 & +4 & +3 & +2 \\
Flavonoid & +5 & +4 & +4 & +3 & +2 & +2 & +1 \\
Triterpenoid & $\mathrm{Ta}$ & $\mathrm{Ta}$ & $\mathrm{Ta}$ & $\mathrm{Ta}$ & $\mathrm{Ta}$ & $\mathrm{Ta}$ & $\mathrm{Ta}$ \\
Sterol & $\mathrm{Ta}$ & $\mathrm{Ta}$ & $\mathrm{Ta}$ & $\mathrm{Ta}$ & $\mathrm{Ta}$ & $\mathrm{Ta}$ & $\mathrm{Ta}$ \\
Saponin & +4 & +4 & +3 & +3 & +3 & +2 & +2 \\
Tanin & +6 & +6 & +5 & +5 & +4 & +3 & +3 \\
Kardiak Glikosida & +5 & +4 & +4 & +3 & +3 & +3 & +3 \\
\hline
\end{tabular}

Keterangan: Tanda (+) menunjukkan intensitas warna, semakin banyak tanda (+) maka semakin kuat intensitas warnanya, sedangkan ( $\mathrm{Ta}$ ) menunjukkan tidak ada (tidak terdeteksi)

proporsional untuk setiap perlakuan, menunjukkan bahwa dalam daun sirsak hanya terdapat senyawa fitokimia dalam kadar yang kecil dibanding yang terdapat di dalam teh. Keberadaan senyawa fitokimia dalam daun dapat berupa aglikon (struktur bebas), terikat secara glikosida atau ester, ataupun membentuk kompleks dengan karbohidrat dan protein. Penyeduhan teh hitam daun sirsak menggunakan air panas menyebabkan putusnya ikatan ester dan glikosida pada senyawa fitokimia dan terekstrak dalam air. Prinsip kelarutan adalah like dissolve like, yaitu pelarut polar akan melarutkan senyawa polar, sebaliknya pelarut non polar akan melarutkan senyawa non polar. Air bersifat polar sehingga senyawa fitokimia dari tepung daun sirsak dan teh hitam yang terekstrak bersifat polar.

Alkaloid memiliki aktivitas antioksidan kerena kemampuannya menangkal radikal bebas DPPH dan mereduksi hidrogen peroksida yang dapat menimbulkan stres oksidatif (Tiong et al., 2013). Flavonoid merupakan senyawa polar karena memiliki sejumlah gugus hidroksil dan larut dalam pelarut polar sperti air, etanol, metanol, butanol dan aseton. Flavonoid memiliki kemampuan sebagai antioksidan dengan mendonorkan atom hidrogen, mentransfer elektron ke senyawa radikal bebas dan membentuk kompleks dengan logam (Dey and Harborne, 1997). Senyawa fenolik merupakan metabolit sekunder yang sangat melimpah dan secara luas terdistribusi di dalam tanaman, senyawa ini memiliki satu atau lebih gugus hidroksil yang melekat pada cincin aromatis, memiliki aktivitas antioksidan, antitumor, antiviral dan antibiotik. Saponin bersifat non toksik terhadap manusia dan bersifat antibiotik (Haryadi, 2012). Tanin merupakan senyawa fenolik yang larut dalam air, mengandung gugus hidroksil dan gugus lain seperti karboksil, senyawa ini memberikan reaksi umum senyawa fenol dan memiliki sifat khusus, yaitu mengikat alkaloid, gelatin dan protein (Ashok dan Upadhyaya, 2012). Tanin dan flavonoid memiliki aktivitas antioksidan dan antimikroba (Wafa et al.,2016).

\section{Total Fenol}

Berdasarkan hasil penelitian (Tabel 2.), dengan peningkatan proporsi daun sirsak dalam seduhan teh hitam daun sirsak memberikan pengaruh nyata terhadap kadar total fenol seduhan. Dalam hal ini tidak ada efek sinergisme antara daun sirsak dan teh hitam. Pada sampel P1 yaitu proporsi yang tersusun oleh teh saja mempunyai kandungan total fenol yang paling tinggi yaitu $25.17 \mathrm{mg} \mathrm{GAE} / \mathrm{L}$ sampel.

Penurunan total fenol pada seduhan teh hitam daun sirsak ternyata bukan karena adanya interaksi antar senyawa fitokimia, namun karena terdapat penurunan senyawa fenolik seiring dengan berkurangnya jumlah teh hitam, berarti semakin banyak penambahan daun sirsak 
Tabel 2. Uji DMRT Total Fenol Minuman Teh Hitam Daun Sirsak

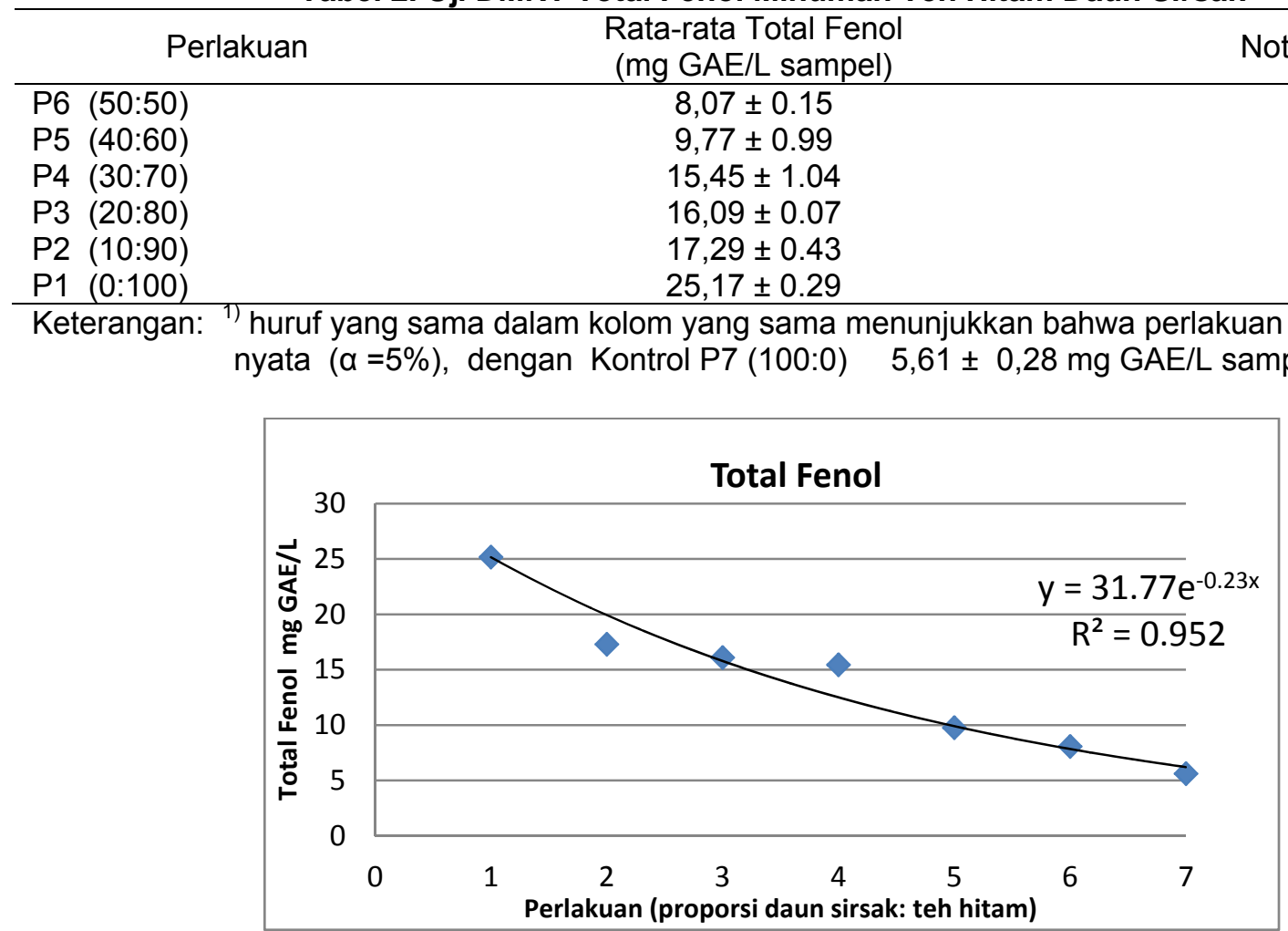

Gambar 1. Kecenderungan Penurunan Total Fenol Minuman Teh Hitam Daun Sirsak

Tabel 3. Uji DMRT Total Flavonoid Minuman Teh Hitam Daun Sirsak

\begin{tabular}{lcc}
\hline Perlakuan & $\begin{array}{c}\text { Rata-rata Total Flavonoid } \\
\text { (mg CE/L sampel) }\end{array}$ & Notasi $^{1)}$ \\
\hline P6 $(50: 50)$ & $1,43 \pm 0.16$ & $\mathrm{a}$ \\
P5 $(40: 60)$ & $2,22 \pm 0.12$ & $\mathrm{~b}$ \\
P4 $(30: 70)$ & $2,61 \pm 0.17$ & $\mathrm{C}$ \\
P3 $(20: 80)$ & $3,04 \pm 0.13$ & $\mathrm{~d}$ \\
P2 $(10: 90)$ & $3,78 \pm 0.18$ & $\mathrm{e}$ \\
P1 $(0: 100)$ & $4,49 \pm 0.09$ & $\mathrm{f}$ \\
\hline
\end{tabular}

Keterangan: " huruf yang sama dalam kolom yang sama menunjukkan bahwa perlakuan tidak berbeda nyata $(\alpha=5 \%)$ dengan Kontrol P7 (100:0): 0,83 \pm 0,09 mg CE/L sampel

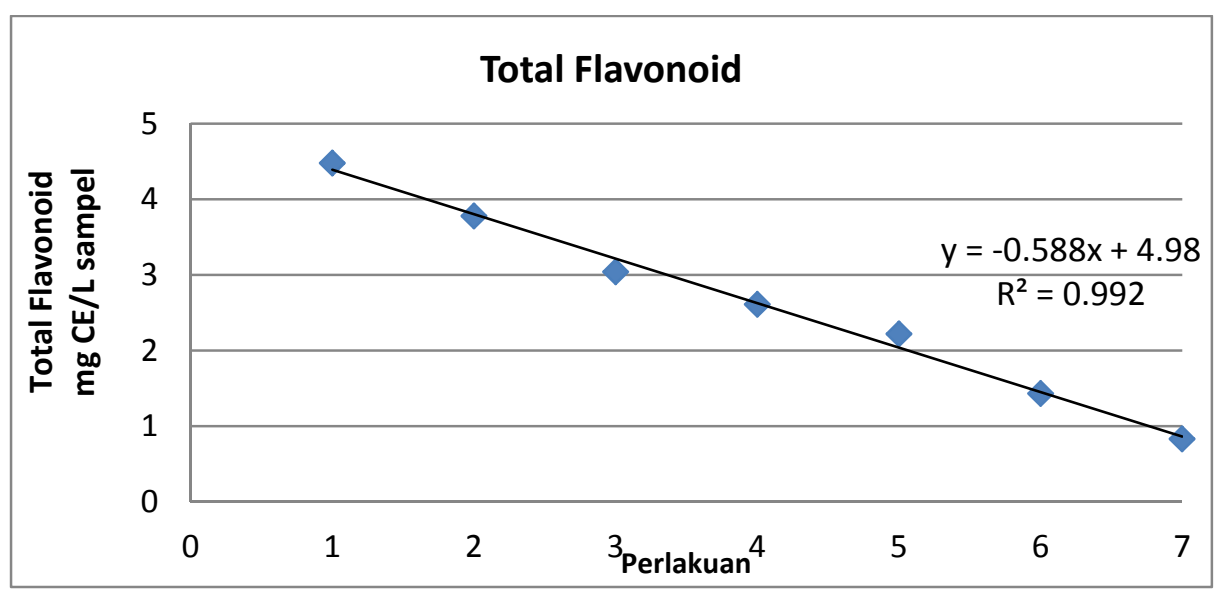

Gambar 2. Kecenderungan Penurunan Total Flavonoid Minuman Teh Hitam Daun Sirsak 
Tabel 4. Uji DMRT Kemampuan Menangkal DPPH Minuman Teh Hitam Daun Sirsak

\begin{tabular}{lcc}
\hline Perlakuan & $\begin{array}{c}\text { Rata-rata Menangkal DPPH } \\
(\text { mg GAE/L sampel) }\end{array}$ & Notasi $^{1)}$ \\
\hline P6 $(50: 50)$ & $1,26 \pm 0.06$ & $\mathrm{a}$ \\
P5 $(40: 60)$ & $1,45 \pm 0.14$ & $\mathrm{ab}$ \\
P4 $(30: 70)$ & $1,76 \pm 0.36$ & $\mathrm{bc}$ \\
P3 $(20: 80)$ & $1,88 \pm 0.21$ & $\mathrm{C}$ \\
P2 $(10: 90)$ & $2,08 \pm 0.20$ & $\mathrm{~cd}$ \\
P1 $(0: 100)$ & $2,47 \pm 0.38$ & $\mathrm{~d}$ \\
\hline Keterangan: & ") huruf yang sama dalam kolom yang sama menunjukkan bahwa perlakuan tidak berbeda \\
& nyata $(\alpha=5 \%)$ dengan Kontrol P7 $(100: 0): 0,63 \pm 0,17$ mg GAE/L sampel
\end{tabular}

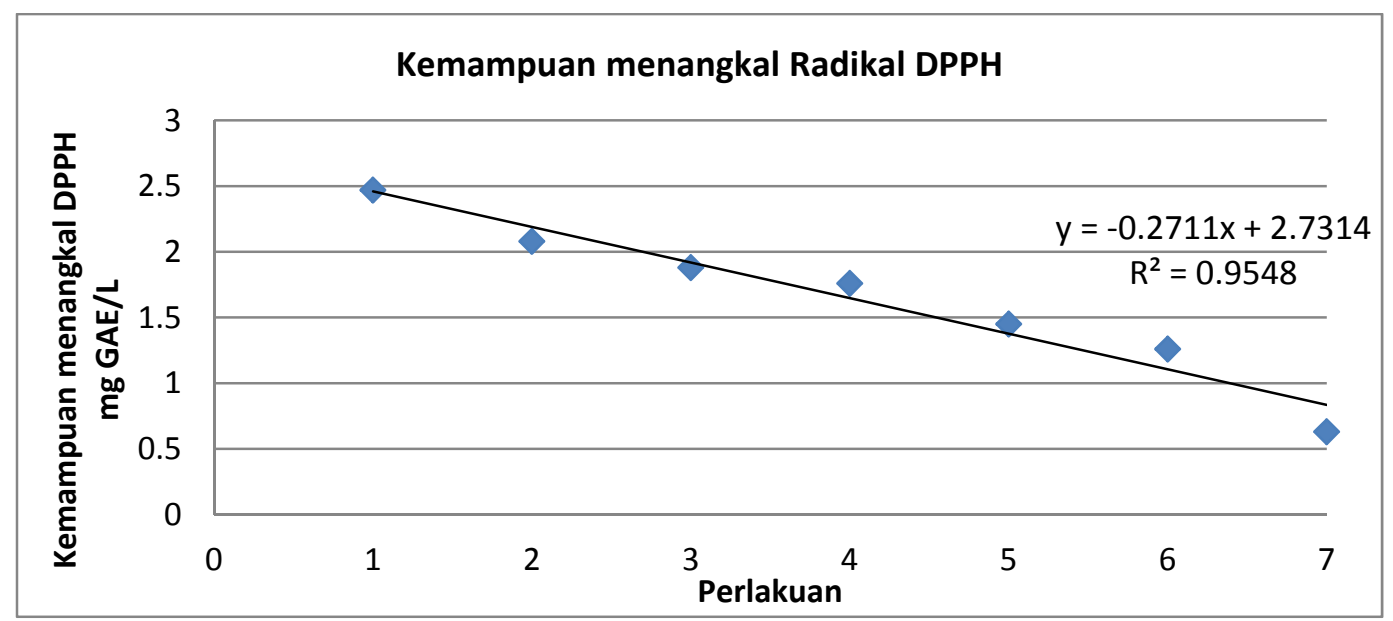

Gambar 3. Kecenderungan Penurunan Kemampuan menangkal DPPH Minuman Teh Hitam Daun Sirsak

justru akan menurunkan kadar total fenol dalam seduhan teh hitam daun sirsak. Penurunan ini mengikuti persamaan eksponensial: $y=31.77 \mathrm{e}^{-0.23 x}$, dengan nilai $R^{2}=0.952$ (Gambar 1.)

\section{Total Flavonoid}

Berdasarkan hasil penelitian (Tabel 3.), dengan peningkatan proporsi daun sirsak dalam seduhan teh hitam daun sirsak memberikan pengaruh nyata terhadap kadar total flavonoid seduhan. Dalam hal ini tidak ada efek sinergisme antara daun sirsak dan teh hitam, sama seperti pada total fenol. Senyawa flavonoid merupakan senyawa dominan dalam golongan fenolik, sehingga hasi uji total flavonoid berbanding lurus dengan hasil uji total fenol. Pada sampel P1 yaitu proporsi yang tersusun oleh teh saja mempunyai kandungan total flavonoid yang paling tinggi yaitu $4,48 \mathrm{mg}$ CE/L sampel.

Penurunan total flavonoid pada seduhan teh hitam daun sirsak ternyata bukan karena adanya interaksi antar senyawa fitokimia, namun karena terdapat penurunan senyawa fenolik seiring dengan berkurangnya jumlah teh hitam, berarti semakin banyak penambahan daun sirsak justru akan menurunkan kadar total flavonoid dalam seduhan teh hitam daun sirsak. Kecenderungan penurunan total flavonoid ini mengikuti persamaan garis linier yaitu $y=-0.588 x+4.98$ dengan nilai $R^{2}=0.992$ (Gambar 2).

\section{Kemampuan Menangkal Radikal Bebas DPPH}

Berdasarkan perhitungan (Tabel 4) diketahui pengaruh proporsi daun sirsak 
Tabel 5. Uji DMRT Kemampuan Mereduksi Ion Besi Minuman Teh Hitam Daun Sirsak

\begin{tabular}{lcc}
\hline Perlakuan & $\begin{array}{c}\text { Rata-rata Total Flavonoid } \\
(\text { mg CE/L sampel) }\end{array}$ & Notasi $^{1)}$ \\
\hline P6 $(50: 50)$ & $28,35 \pm 0.21$ & $\mathrm{a}$ \\
P5 $(40: 60)$ & $33,59 \pm 0.72$ & $\mathrm{~b}$ \\
P4 $(30: 70)$ & $37,27 \pm 0.44$ & $\mathrm{C}$ \\
P3 $(20: 80)$ & $44,29 \pm 0.33$ & $\mathrm{~d}$ \\
P2 $(10: 90)$ & $51,00 \pm 0.58$ & $\mathrm{e}$ \\
P1 $(0: 100)$ & $54,25 \pm 0.90$ & $\mathrm{f}$ \\
\hline Keterangan: & ") huruf yang sama dalam kolom yang sama menunjukkan bahwa perlakuan tidak berbeda \\
& nyata $(\alpha=5 \%)$ dengan Kontrol P7 (100:0) $: 19.47 \pm 0,96$ mg GAE/L sampel
\end{tabular}

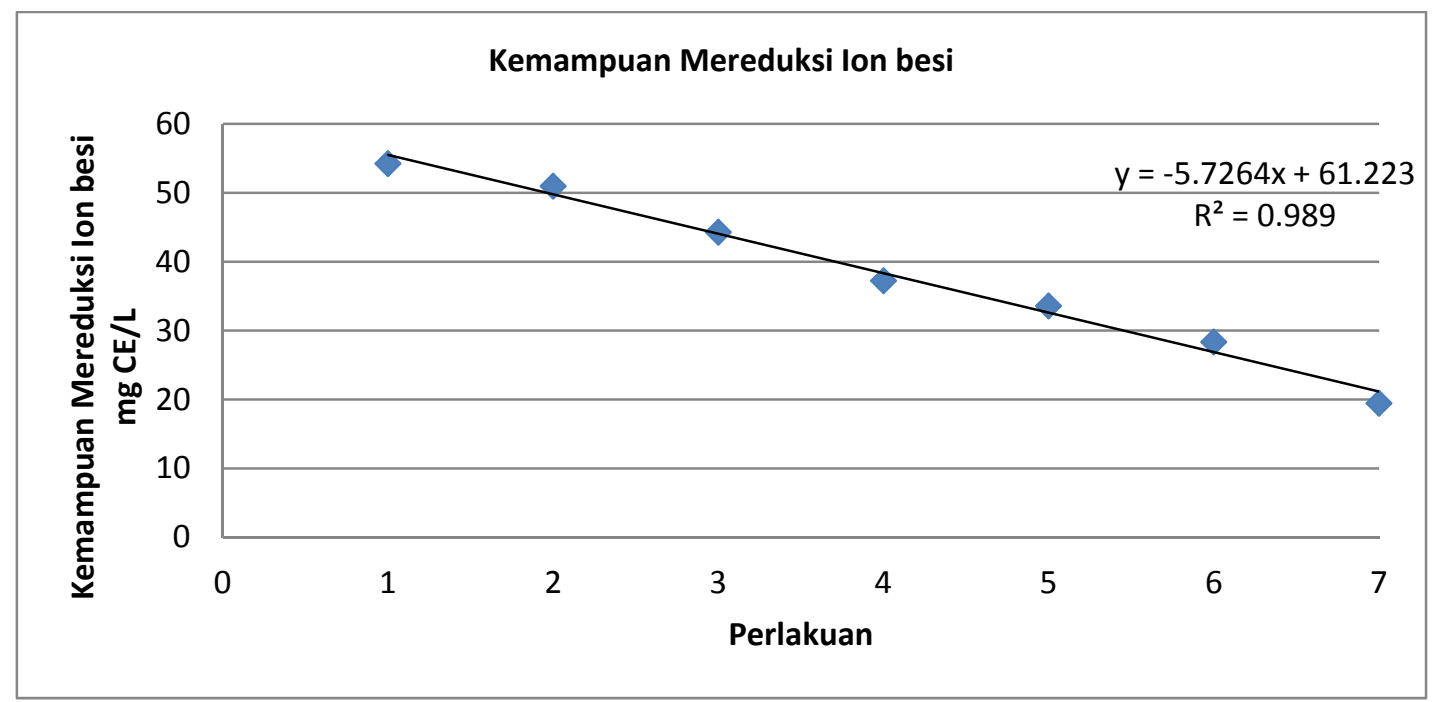

Gambar 4. Kecenderungan Penurunan Kemampuan Mereduksi lon besi Minuman Teh Hitam Daun Sirsak

yang ditambahkan memberikan pengaruh nyata terhadap kemampuan menangkal radikal bebas DPPH. Hasil uji aktivitas antioksidan metode DPPH seiring dengan hasil uji senyawa fitokimia, total fenol dan total flavonoid, yaitu menunjukkan kemampuan menangkal radikal bebas DPPH berkurang seiring dengan bertambah besarnya proporsi tepung daun sirsak. Semakin besar total fenol dan total flavonoid maka semakin besar potensi seduhan teh hitam daun sirsak dalam menangkal radikal bebas DPPH. Kapasitas menangkal radikal bebas DPPH sebagian besar terkait dengan gugus hidroksil dari senyawa fenol. Penurunan warna ungu disebabkan radikal DPPH menangkap[ atom hidrogen atau elektron bebas yang didonorkan oleh senyawa fenolik di dalamnya termasuk juga golongan flavonoid (Yu Lin et al., 2009). Dari percobaan diketahui pada sampel P1 yaitu proporsi yang tersusun oleh teh hitam saja mempunyai kemampuan menangkal radikal bebas DPPH yang paling tinggi yaitu 2,47士 $0.38 \mathrm{mg}$ GAE/l sampel mg GAE/L sampel. Dari uji DMRT terlihat hal yang menarik dengan adanya pasangan perlakuan yang mempunyai nilai sama, yaitu P6 (notasi a) dan P5 (notasi ab), pasangan P5 (notasi ab) dengan P4(notasi bc), pasangan P4(notasi bc) dengan P3(notasi $c$ ), pasangan P3(notasi c) dengan P2(notasi cd), dan pasangan P2 dengan P1 (notasi d). Dari perhitungan didapatkan, kecenderungan penurunan kemampuan menangkal DPPH dari seduhan teh hitam daun sirsak ini mengikuti persamaan garis linier yaitu $y=$ $0.271 x+2.731$ dengan nilai $R^{2}=0.954$ (Gambar 3). 


\section{Kemampuan Mereduksi Ion Besi}

Dari hasil penelitian (Tabel 5), diketahui bahwa perbedaan proporsi tepung daun sirsak yangdtitambahkan memberikan pengaruh nyata terhadap kemampuan mereduksi ion besi. Hasil uji kemampuan mereduksi ion besi seiring dengan hasil uji senyawa fitokimia, total fenol, dan total flavonoid yang menutrun siring bertambahnya tepung daun sisrsak yang ditambahkan. Semakin besar total fenol dan total flavonoid maka semakin besar kemampuan minuman teh hitam daun sirsak dalam mereduksi ion $\mathrm{Fe}^{3+}$ menjadi $\mathrm{Fe}^{2+}$. Bersamaan dengan kemampuan menangkap radikal bebas DPPH, kapasitas mereduksi ion besi juga terkait dengan gugus hidroksil yang ada pada senyawa fenol. Kapasitas reduksi ion besi $\mathrm{Fe}^{3+}$ dan $\mathrm{Fe}^{2+}$. oleh senyawa fenol dan flavonoid disebabkan karena senyawa ini memiliki kemampuan mendonorkan elektron bebasnya dan berperan sebagai reduktor. Kemampuan senyawa fenol dan flavonoid sebagai reduktor dapat menurunkan sifat ion $\mathrm{Fe}^{3+}$ sebagai katatalis oksidasi (prooksidan). Keberadaan reduktan dalam seduhan teh hitan daun sisrsak dapat memutus rantai radikal bebas dengan mendonorkan atom hidrogen sehingga mampu mereduksi $\mathrm{Fe} 3+$ menjadi $\mathrm{Fe}^{2+}$. Kemampuan mereduksi ion besi merupakan salah satu mekanisme aksi utama antioksidan yang ditunjukkan oleh senyawa fitokimia fenolik, oleh karena itu seduhan teh hitam daun sirsak yang memiliki total fenol dan total flavonoid yang tinggi juga memiliki aktivitas antioksidan dalam mereduksi ion besi yang tinggi pula. Kemampuan mereduksi ion besi paling tinggi ditunjukkan oleh $\mathrm{P} 1$ yaitu seduhan teh hitam saja sebesar 54,25 $\pm 0,90 \mathrm{mg}$ GAE/L. Kecenderungan penurunan kemampuan mereduksi ion besi ini mengikuti persamaan linier yaitu $y=-5.726$ $x+61.22$ dengan nilai $R^{2}=0.9899$ (Gambar 4).

\section{KESIMPULAN}

Peningkatan proporsi penambahan daun sirsak dalam seduhan teh hitam daun sirsak menyebabkan penurunan senyawa fitokimia, total fenol, total flavonoid, kemampuan menangkal radikal DPPH dan kemampuan mereduksi ion besi seduhan teh hitam daun sirsak. Hasil penelitian menunjukkan kadar total fenol berkisar antara 5,61-25,17 mg GAE/L sampel, kadar total flavonoid berkisar anatara 0,83-4,48 mg CE/L sampel, kemampuan menangkal radikal bebas DPPH berkisar anatara 0,63 2,47 mg GAE/L sampel, dan kemampuan mereduksi ion besi berkisar antara 19,47 54,25 mg GAE/L sampel.

\section{UCAPAN TERIMA KASIH}

Terima kasih kepada Lembaga Layanan Dikti Wilayah VII (LL Dikti VII) dan Kementrian Riset Teknologi dan Pendidikan Tinggi Republik Indonesia atas dana yang diberikan melalui penelitian hibah bersaing.

\section{DAFTAR PUSTAKA}

Abeywickrama K.R.W., W.D. Ratnasooriya, A.M.T. Amarakoon, 2011. Oral hypoglycaemic, antihyperglycaemic and antidiabetic activities of Sri Lankan Broken Orange Pekoe Fannings (BOPF) grade black tea (Camellia sinensis L.) in rats .Journal of Ethnopharmacology, Volume 135, Issue 2, 17 May 2011, Pages 278-286

Aguilar-Hernandez G., Garcia-Magana M. L., Vivar-vera M.A, et al., 2019. Optimization of Ultrasound-Assisted Extraction of Phenolic Compounds From Annona muricata By-Products and Pulp. Molecules 2019, 24(5),904. https://doi.org/10.3390/molecules 2405 $\underline{0904}$.

Al-Temimi A. and R Choudhary, 2013. Determination of Antioxidant Activity in 
Different Kinds of Plant in vivo and in vitro by using diverse technical methods. Journal Nutrition of food Science 3:1-9.

AOAC, 2005. Method of Analysis. Washington: Association of official Analytical Chemistry.

Ashok dan Upadhyaya, 2012. Tannins are Astringent. Journal of Pharmacognosy and Phytochemstry 1(3):45-50.

Chang C., M. Yang, H. Wen and J. Chern, 2002. Estimation of Total Flavonoid Content in Propolis by Two Complementary Colorimetric Methods. Journal of Food and Drug Analysis 1:178-182.

Dey P.M., and J.B.Harborne, 1997. Plant Biochemsistry. USA: Academic Press

Graham, H.N., 1992. Green tea Compositions, Consumption, and Polyphenol, Chemistry. Preventive Medicine 21(3):334-350.

Harborne, J.B.,1987. Phytochemicals Method $2^{\text {nd }}$ Edition. New York: Chapman and Hall.

Harborne, 1996. Metode Fitokimia, penterjemah Padmawinata $\mathrm{K}$. dan I. Sudira. Bandung: Institut Teknologi Bandung.

Hermawan G.P., H Laksono dan I. Sumantri, 2013. Ekstraksi Daun Sirsak (Annona muricata L.) menggunakan pelarut Etanol. Jurnal Teknologi Kimia dan Industri 2(2).

Jain, N.K., M. Siddiqi, and John Weisburger,2006. Protective Effects of
Tea on Human Health. CAB International:Cambridge,USA.

Kris-Etherton P.M., K.D. Hecker, A. Bonanome, T.D. Etherton, 2003. Bioactive Compounds in Foods: Their Role Prevention ofCardiovascular Disease and Cancer. The American Journal of Medicine. 113 Suppl 9B:71S-88S

Ljubuncic P., Azaizeh H, Portnaya I, Cogan U, Said O, Saleh KA, Bomzon A., 2005. Antioxidant activity and cytotoxicity of eight plants used in traditional Arab medicine in Israel, Journal of Ethnopharmacology 99 : 43-47.

MackenzieT., Laery L., Brooks W.B., 2007. The effect of extract of green and black tea on glucose control in adults with type 2 diabetes mellitus: doubleblind randomized study. Metabolism 2007 Oct; 56(10):1340-4

McDonald,S., P.D.Prenzler, M. Antolovich, K. Robards, 2001. Phenolic content and antioxidant activity of olive extracts. Food Chemistry, Vol 73, 1, April 20001, p73-84. https://doi.org/10.1016/S03088146(00)00288-0

Najmudin S.U.F.S., M.F Romli, M. Hamid, N. B. Alitheen, and N.M.A.N.A. Rahman, 2016. Anti-cancer effect of Annona Muricata Linn Leaves Crude Extract (AMCE) on breast cancer cell line. BMC Complementary and Alternarive Medicine (2016) 16:311. DOI: 10.1186/s12906-016-1290-y

Nishiumi S., Bessyo H., Kubo M., Aoki Y., Tanaka A.,Yoshida K., Ashida 
H.,2010. Green and black tea duppress hyperglycemia and insulin resistance by retaining the expression of glucose transporter 4 in muscle of high-fat diet-fed C57BL/6J mice. J.Agric FoodChem, 2010 Dec 22; 58(24):12916-23. Doi:

10.10201/jf102840w.Epub.2010Nov

24.

Osathanunkul M., 2018. Bar-HM for authenticating soursop (Annona muricata) tea. Sci Rep 2018. Aug 23;8(1):12666. Doi:10.10338/s41598018-31127-9

Rekha, C.G. Poornima, M. Manasa, V. Abhipsa, J. P. Devi, H.T.V. Kumar and T.R.P Kekuda, 2012. Ascorbic acid, Total Phenol Content and Antioxidant Activity of Fresh Juices of Four Ripe and Unripe Citrus Fruits. Journal of Chemical Science Transactions 1(2):303-310.
Tiong S.H., C.Y Looi, H. Hazni, A. Arya, M. Paydar, W.F. Wong, S.C. Cheah, M. R. Mustafa, and K. Awang, 2013. Antidiabetic and antioxidants Properies of Alkaloids from Ctharanthus roseus (L) G. Don. Molecules 18(8):9770-9784.

Wafa N., G. Sofiane,K. Mouhamed, 2016. The Antioxidant and antimicrobial activities of flavonoid andtannins extracted from Phlomis bovei De Noe. European journal of experiental biology,2016, 6(3): 55-61

Yu Lin, H. Kuo, Y.H. Lin, and Y.L. Chiang, 2009. Antioxidative Effects and Active Componen from Leaves of Lotus (Nelumbo nucifera). Journal of Agricultural and Food Chemistry 57:6623-6629. 